\title{
A Comparative Study between Presentation, Practice, Productive (PPP) and Artworks Techniques toward the Enhancement of Students' Descriptive Writing Skills
}

\author{
Fransiska Masta Rotua Silalahi \\ Email address:frans_mazt@yahoo.co.id \\ English Teacher at TK, SD, SMP Advent II, Bandung
}

\begin{abstract}
The aim of this study is to find out whether there is any significant difference in enhancing students' descriptive writing skills between students who acquires Presentation, Practice, Production (PPP) and students who acquires Artworks Technique. This is a quantitative study, utilizing comparative design in order to compare different treatments toward students' enhancement in descriptive writing skills. The researcher compares the result through pre-test and post-test. After analyzing the data, the researcher found out after being treated using two techniques: PPP and Artworks, students' skills in descriptive writing is achieved. However, the normalized gain score falls in Low criterion. Aside from that, based on the data analysis there is significant difference between two techniques: PPP and Artworks in enhancing students' descriptive writing skills. In addition to that, the students give positive response after being treated. From the response questionnaire, the mean score falls in High criterion. The scope and delimitations of this study evolve around components of two techniques: PPP and Artworks to provide insights toward enhancing students' ability in writing descriptive text.
\end{abstract}

Keywords Presentation Practice Production (PPP), Artworks, Descriptive Writing Skills

\section{INTRODUCTION}

Learning English language leads students to learn four macro skills; they are speaking, listening, reading and writing. Practically, writing is taught to be the last skill after speaking, listening and reading. However, it does not mean that writing is not imperative of all skills. As a matter of fact, writing is life that presents human emotions as well as human experiences. Sharples (cited in Sumarsih \& Sanjaya, 2013) actually said that writing is an opportunity which allows English learners to explore and explain 
ideas or thoughts. They can deliberate their ideas in their minds by organizing them into effective paragraphs.

However, Warschauer (cited in Kitchakarn, 2014) stated that writing can be considered as an irksome learning experience for some students who do not have sufficient ideas, knowledge and skills to process. Richards and Renandya (2003) concurred that writing is difficult skill to develop for second language learners because in order to write an effective writing, a person must comprehend the writing components of the target language. In addition to that, Grabe and Kaplan (1996) assumed that half of the world's population have low ability to write adequately and effectively. There are several obstacles in writing English that students encounter such as limited knowledge and skills in English structure, limited word choices, and culture influence which have been researched by many researchers in this field (Ghabool, Marriadas \& Kashed, 2012; Kaewnuch, 2008: Kamimura, 2010; Wong, Chin, Chen \& Gao, 2009 as cited in Sufatmi and Aizan, 2016). Therefore, learning to write has always been one of the most complex language skills. Nunan (1989) agreed that it is easier to learn to speak than to write no matter if it is the first or second language. It is not an easy task to enhance since it requires hard work, lengthy steps, enough time, and more practice.

In teaching writing to English learners, teachers often introduce the four most common types of writing (Richards \& Schmidts, 2002 cited in Suyatmi \& Yaacob, 2016). However, of all four types of writing, descriptive writing is the most basic form of writing. Therefore, in order to improve learners' writing skills, teachers can start by requiring their students to write descriptive text. Descriptive text is one genre that is imperative to be learned by English learners. According to Evawina (cited in Sumasih \& Sanjaya, 2016), through descriptive text, learners can learn to visualize and vividly portray a person, place or thing in such a way that the readers can visualize the topic and enter into the writer's experience. Nevertheless Farooq (2013) stated that many English learners were struggling to write descriptive text. They have difficulty to differentiate between descriptive and narrative writings. It is because the students have limited vocabulary to vividly describe the characters and express their ideas into writing. In addition to that, Hasnun (2006) accentuated that English learners should be able to involve the imaginative senses to develop descriptive writing yet choosing appropriate words to describe the objects and then is a difficult task; they end up making incorrect sentence structure.

Generally, high school students feel more enjoyable to learn when the atmosphere is conducive in the class. Therefore, the researcher conducted a comparative study between Presentation, Practice and Production (PPP) by Anthony (1963) and Artwork techniques to enhance students' descriptive writing ability. The researcher has considered these two techniques to be compared by looking at the components of each technique toward the enhancement of students' descriptive writing skills. 
PPP technique consists of three stages: Presentation, Practice and Production. In the presentation stage, the teacher is the one who controls the teaching and learning process; in Practice stage, the teacher is responsible to check the learners' comprehension in deliberating ideas or thoughts. In the last stage which production, learners should be able to increase their linguistic use through autonomous and more activities (Richard, 2006; Harmer, 2007; Sato, 2010, and Shekan, 1998). Meanwhile Artwork Technique is a technique to lead English learners to stimulate their imagination in building their ideas or thoughts. Through this technique, students will improve their critical thinking skills. Especially in learning descriptive text, learners will be able to integrate arts to deepen their understanding on human experiences. Artwork technique provides rich experiences in describing, analysis, exploration, reflection, observation, imagination, experimentation, and communication (Evan, 2010; Merryl, 2010).

These two techniques are effective in enhancing students' descriptive writing skills. Particularly, this study seeks to find out whether PPP and artworks techniques give positive impact in learning process to enhance students' ability in descriptive writing. This study aims to answer the following questions:

1. What is the achievement between the students who are treated using PPP technique and students who are treated using artworks technique?

2. Is there any significant difference between the use of PPP and Artworks techniques to enhance students' descriptive writing skills?

3. What is the response of the students after being treated using PPP and students after being treated using Artworks. 


\section{METHODOLOGY}

In conducting the research, the researcher applied quantitative research design. According to Fraenkel and Wallen (2006), comparative research is a study that aims to compare the effect of treatments, in which the participant is assigned to one of two or more different treatment groups. So, comparative research is an activity to compare the different treatment in order to get the result of both treatment. This research is dealt with score to find out whether there is enhancement on students' ability in writing descriptive text, the researcher compared the result of the pretest and posttest. The participants of this study are $10^{\text {th }}$ graders from SMAN 1, Lembang. The respondents were divided into two groups: IPS 3 was treated using PPP technique and IPS 5 was treated using Artworks Technique. In terms of research instrument, the researcher utilized pre-test and post-test. The tests were given to find out the significant difference between students who received different treatments. The tests consist of several parts: describing pictures, building effective paragraphs, arranging sentence and finishing incomplete texts using appropriate words. In analyzing the data, the researcher utilized normalized gain, normality test, homogeneity test and difference of two means test.

\section{RESULT AND DISCUSSION}

After making a careful analysis, the researcher found out the answers to the research questions. The following table is to find out students' achievement after being treated:

Table 1. Pre-Test, Post Test, Standard Deviation and Normalized Gain

\begin{tabular}{|c|c|c|c|c|}
\hline & Mean & St. Deviation & Mean & $\begin{array}{c}\text { St. } \\
\text { Deviation }\end{array}$ \\
\hline Pre - Test & 55,86 & 7,402 & 60,25 & 9,391 \\
\hline Post - Test & 66,82 & 7,543 & 66,29 & 7,164 \\
\hline Normalized & 0,24 & 0,126 & 0,13 & 0,136 \\
\hline Gain & & & & \\
\hline
\end{tabular}

Based on the data above, it can be seen from the pre-test that both groups have the same level of skills in writing descriptive text. After each group was treated, there was an achievement, it is shown in the table that the post-test result of PPP group is 66, 82 and the post-test of Artworks group is 66, 29. Nevertheless each of the normalized gain of both groups falls to a Low criterion: the normalize gain of PPP group is 0.24 and the normalized gain of Artworks group is 0.13 . In terms of standard deviation, as shown 
in the table, the Artworks group's standard deviation is lower after the treatment was given, from 9.391 became 7.164 which means most of the students experienced enhancement in their descriptive writing skills.

After finding out the achievement of both groups, the researcher seeks to discover whether there is significant difference between both techniques: PPP and Artworks in enhancing students' descriptive writing skills. Therefore the researcher analyzed the data through Normality Test of Gain Score to find the answer. The following is the result:

Table 2

\begin{tabular}{|c|c|c|c|}
\hline \multirow{2}{*}{ Group } & & Shapiro - Wilk & \\
\cline { 2 - 4 } & Statistic & df & Sig. \\
\hline Gain PPP & 0.980 & 28 & 0,853 \\
\hline $\begin{array}{c}\text { Score } \\
\text { Artwork }\end{array}$ & 0.962 & 28 & 0,388 \\
\hline
\end{tabular}

Based on the data table above, both data is normally distributed because the significant value of the gain score for PPP group is 0.853 which is greater than $\alpha(0.05)$ and the significant of the gain score for Artworks group is 0.388 which is greater than $\alpha$ (0.05).

Table. 3. Homogeneity Test of Gain Score

\begin{tabular}{|c|c|c|l|}
\hline Levene Statistic & df1 & df2 & Sig. \\
\hline 0,011 & 1 & 54 & 0,915 \\
\hline
\end{tabular}

The data is homogeneous if $p$-value is greater than $\alpha(0.05)$ and if the value is equal or lesser than $\alpha(0.05)$, it means data is not homogeneous. Based on the result of the table 3, the result of the data between PPP and Artworks are homogeneous because 0.915 is greater than $\alpha(0.05)$.

Since the normalized gain population was normally distributed and the data is homogenous, then the independent sample t-test was done to answer the research question: 'Is there any significant difference between the use of PPP and Artworks 
techniques to enhance students' descriptive writing skills?' The following is the result calculation, as seen in the table below

Table 4. The Result of Independent Sample T-Test of Normalized Gain

\begin{tabular}{|l|c|c|c|c|c|}
\hline \multirow{2}{*}{} & \multicolumn{2}{|l|}{ Levene's Test } & \multicolumn{2}{l|}{ t-test } \\
\cline { 2 - 6 } & $\mathrm{F}$ & Sig. & $\mathrm{T}$ & $\mathrm{df}$ & Sig. (2-tailed) \\
\hline Equal variances & 0,011 & 0,915 & 3,075 & 54 & 0,003 \\
Assumed & & & & & \\
\hline Equal variances not & & & 3,075 & 53,730 & 0,003 \\
Assumed & & & & & \\
\hline
\end{tabular}

Since the population variances of the normalized gain score are homogeny, the row of equal variances assumed is utilized. The result shows that the value of the gain score is 0.003 which is lesser than $\alpha(0.05)$, so it can be concluded that $\mathrm{H} 0$ is rejected. Thus, it means that there is significant difference between those who taught by using PPP and artworks in enhancing students' descriptive writing skills.

In order to find out students' response after being treated toward the enhancement of their descriptive writing skills, the researcher distributed questionnaire to be filled out by the students. The result shows in the following table: 
Table. 5. Students Response toward the Techniques

\begin{tabular}{|c|c|c|}
\hline & PPP & Artworks \\
\hline $\begin{array}{c}\text { Mean of the } \\
\text { Questionnaire Result }\end{array}$ & $77 \%$ & $79 \%$ \\
\hline
\end{tabular}

Based on the table above, the mean score of students' response toward PPP technique is $77 \%$ and mean score of students' response toward Artworks Technique is $79 \%$. In accordance to the interpretation, both techniques fall on high criteria. It means that both techniques received good response from both group of students.

From the result of the data, it shows that there is significant difference in enhancing students' ability in writing descriptive text between those who taught by using PPP and artworks. It can be said, that there is significant difference from the gain of both techniques. The data shows that the gain score of PPP is 0.24 and the gain score of Artworks is 0.13 . The following is the summary of this study:

1. There is an enhancement of students' descriptive writing skills in each group. Both techniques help students enhance their skills. However, if the score is compared, PPP group obtains higher enhancement than the Artworks group.

2. Based on data analysis, the result of null hypothesis is rejected which means that there is significant difference in enhancing students' skills in writing descriptive text.

3. The students' response toward PPP is $77 \%$ and students' response toward Artworks Technique is $79 \%$. In accordance to the interpretation, both techniques are in high criteria. It means that both techniques receive good response from both group of students.

However, both gain scores fall in Low criterion. It is assumed that one of the factors that may cause the gain scores to be in Low category is language barrier. The students often use 'Bahasa Sunda' as their means of communication. They translated English word to Indonesia then to Sundanese. In addition to that, due to the students' limited vocabulary, they frequently misused English words in descriptive writing. 


\section{REFERENCES}

Farooq, U. (2013). Focus on the Difficulties of Writing Descriptive Essay. Jakarta

Fraenkel, Jack R, and Norman E. Wallen. (2006). How to Design and Evaluate Research in Education, Sixth Edition. Boston: McGraw Hill.

Grabe, W. \& Kaplan, B. (1996). Theory and practice of writing. London \& New York: Longman.

Hasnun, A. (2006). Pedoman menulis untuk siswa SMP dan SMA. Jakarta: Pustaka Belajar.

Kitchakarn, O. (2014). Developing Writing Abilities of EFL Students Through Blogging. Turkish Online Journal of Distance Education-TOJDE. 15 (4), pp. 34-46.

Nunan, D. (1989). Designing tasks for the communicative classroom. Cambridge: Cambridge University Press.

Richards, J. C., \& Renandya, W. A. (2003). Methodology in language teaching: An anthology of current practice. $3^{\text {rd }}$ ed. Cambridge University Press.

Sumarsich \& Sanjaya, D. (2016). TPS as an Effective Technique to Enhance the Students' Achievement on Writing Descriptive Text. English Language Teaching. 6 (12). 106113.

Supranto, J. (2009). Statistik Teori dan Aplikasi. Jakarta: Erlangga. 